\title{
Full Characterization of Erisma uncinatum Warm Wood Specie
}

\author{
Francisco Antonio Rocco Lahr ${ }^{1}$, Felipe Nascimento Arroyo ${ }^{2}$, Tiago Hendrigo de Almeida ${ }^{3}$, \\ Fernando Menezes de Almeida Filho ${ }^{2}$, Igor Santos Mendes², André Luis Christoforo ${ }^{2, *}$
}

${ }^{1}$ Department of Structural Engineering (SET), São Carlos Engineering School, São Paulo University (EESC/USP), São Carlos, Brazil ${ }^{2}$ Department of Civil Engineering (DECiv), Federal University of São Carlos (UFSCar), São Carlos, Brazil

${ }^{3}$ Department of Science and Material Engineering, São Carlos Engineering School (SMM), São Carlos, Brazil

\begin{abstract}
Wood is a material that for years has been used by man for a variety of purposes, particularly in rural and civil constructions. For the possibility of shortages of some wood species, the characterization of other little known species as alternatives is necessary. This research aimed to determine, with the aid of the Brazilian standard NBR 7190, physical and mechanical properties of Cambará rosa or Cedrinho wood (Erisma uncinatum Warm), and with the support of regression models (linear, exponential, geometric, logarithmic) based on analysis of variance (ANOVA), to estimate the values of strength and stiffness as a function of apparent density, for the density being a property of easy determination. Were obtained 12 determinations by physical and mechanical propertie, resulting in 204 experimental results. The mechanical properties of Erisma uncinatum Warm presented performance compatible with other species used in civil construction, but not being considered a high strength wood. By means of regression models to estimate the strength and stiffness values, it was found that no property can be estimated by the apparent density.
\end{abstract}

Keywords Characterization, Erisma uncinatum Warm, Regression model, Analysis of variance (ANOVA)

\section{Introduction}

The use of wood in construction is a practice carried out for many years by mankind from the need to stock up on food, overcoming obstacles to the construction of shelters [1]. Using wood in various purposes depends on the knowledge of its properties (physical, chemical, mechanical and anatomical) for more rational use of this material, which comes from natural sources, perfectly fulfills the requirements by the current environmental appeal of products and service furnish by mankind $[2,3]$.

The high demand allied with few wood species traded options has impacted on its prices, providing a new moment for the Brazilian timber industry, being necessary to define which new species could replace the traditionally used in construction [4-6]. Moreover, with the growing awareness of the population to use materials that cause the least harm to the environment, the wood from planted forests becomes a material with great potential [6].

Therefore, the wood Erisma uncinatum Warm (Figure 1) becomes a great option, especially to the north and a small part of the center-west region of Brazil, where the production

* Corresponding author:

alchristoforo@gmail.com (André Luis Christoforo)

Published online at http://journal.sapub.org/ijme

Copyright (C) 2016 Scientific \& Academic Publishing. All Rights Reserved of this wood specie is more pronounced [7].

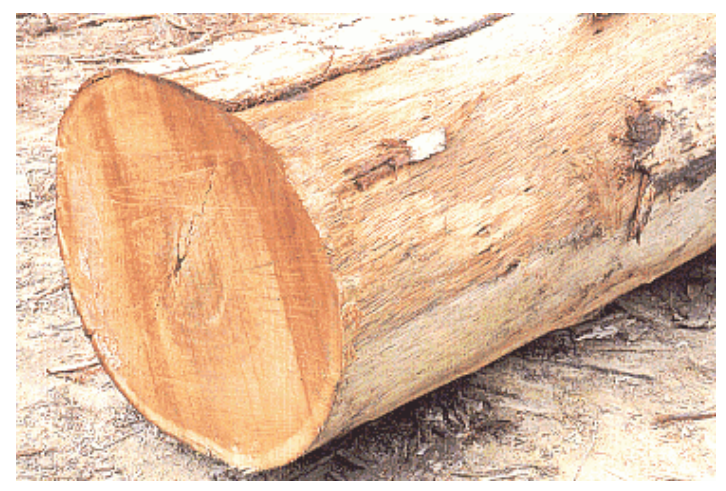

Figure 1. Image of the Erisma uncinatum Warm Wood. Source: http://artemarcenaria.blogspot.com.br/2011/07/ficha-tecnica-cedrinho.html

By the density of the wood Erisma uncinatum Warm $\left(0.650 \mathrm{~g} / \mathrm{cm}^{3}\right)$, it is also indicated for the glued laminated timber production and also provide adhesive compatibility [8]. It is worth mentioning that the use of a particular species of wood in construction, as well as any other material, the knowledge of its physical and mechanical properties is essential for the project, which allows a more economical and safe design.

The characterization of wood species is made by determining its mechanical and physical properties by standardized tests. In Brazil, the standard ABNT NBR 7190 [9] defines the parameters for its characterization. However, 
the drawback of many such tests is the need to use large and expensive equipment available in research centers [9].

On the other hand, a physical property of easy experimental determination is the apparent density, defined by the ratio between the mass and volume of the sample at $12 \%$ moisture. As the density is a basic physical property, its values allows the determination of an adequate estimation of the wood properties $[2,10]$. The estimatimation of some properties of strength and stiffness by density via mathematical models (regression models) enables to the engineer a better pre-sizing of the structure.

In order to contribute to the use of new wood species in rural and construction, as well as in other applications, this study aimed to characterize the Erisma uncinatum Warm wood specie and evaluate the possibility of estimating the strength and stiffness properties investigated by the apparent density.

\section{Material and Methods}

The wood samples of the Erisma uncinatum Warm has been properly stored, with close to $12 \%$ moisture content, and this is the moisture balance established by the Brazilian standard [9].

All tests were carried out on the Laboratory of Wood and Wood Structures (Laboratório de Madeira e de Estruturas de Madeira - LaMEM), at the São Carlos Engineering School (EESC), University of São Paulo (USP).

The physical and mechanical properties (Table 1) were obtained according to the assumptions and calculation methods given by the Brazilian standard ABNT NBR 7190 [9] (Wooden Structures Project), provided on its Annex B. It should be noted that 12 values for each one of its physical (3) and mechanical properties (14) were investigated, resulting in a total of 204 experimental values obtained.

In addition to obtaining the physical and mechanical properties listed in Table 1, the wood Erisma uncinatum Warm has been properly classified in the timber strength classes [9], defined by determining its characteristic value of compressive strength parallel to the grain $\left(\mathrm{f}_{\mathrm{c} 0, \mathrm{k}}\right)$.

To estimate the strength and the stiffness properties $(Y)$, as a function of the apparent density $\left(\rho_{12}\right)$ of the Erisma uncinatum Warm wood specie, regression models were used (Equations 1 to 4) based on analysis of variance (ANOVA), tested in a way to establish the best fit for estimated property.

$$
\begin{array}{rlrl}
Y & =a+b \cdot \rho_{12} & {[\text { Lin - linear }]} \\
Y & =a \cdot e^{b \cdot \rho_{12}} \quad[\text { Exp - exponential }] \\
Y & =a+b \cdot \operatorname{Ln}\left(\rho_{12}\right) \quad[\text { Log - logarithmic }] \\
Y & =a \cdot \rho_{12}{ }^{b} \quad[\text { Geo - geometric }]
\end{array}
$$

By ANOVA regression models, considering the $5 \%$ level of significance $(\alpha)$, the formulated null hypothesis consisted by the non-representativeness of the tested models $\left(H_{0}: \beta=\right.$ 0 ), and the representativeness as an alternative hypothesis
$\left(H_{1}: \beta \neq 0\right)$. P-value greater than the significance level implies in the accepting $\mathrm{H}_{0}$ (the model tested is not representative $-\rho_{12}$ variations are unable to explain the variation in strength and stiffness property), refuting it otherwise (the model tested is representative).

Besides the use of ANOVA, which allows to accept or not the representativeness of the tested models, the coefficient of determination values $\left(\mathrm{R}^{2}\right)$ were obtained as a way to evaluate the variation capability in the apparent density to explain the estimated dependent variable, making it possible to determine, among the considered significant models (4 models for each of the 14 strength properties and estimated stiffness - resulting in 56 adjustments), the ones with the best fit.

Table 1. Mechanical and physical properties measured for the Erisma uncinatum Warm wood specie

\begin{tabular}{lc}
\hline \multicolumn{1}{c}{ Propertie } & Notation \\
\hline Apparent density & $\rho_{12}$ \\
Total radial Shrinkage & $\mathrm{RRT}$ \\
Total tangencial Shrinkage & $\mathrm{RTT}$ \\
Compressive strength parallel to the grain & $\mathrm{f}_{\mathrm{c} 0}$ \\
Tensile strength parallel to the grain & $\mathrm{f}_{\mathrm{t} 0}$ \\
Tensile strength normal to the grain & $\mathrm{f}_{\mathrm{t} 90}$ \\
Shear strength parallel to the grain & $\mathrm{f}_{\mathrm{v} 0}$ \\
Splitting strength & $\mathrm{f}_{\mathrm{s} 0}$ \\
Conventional strength on static bending test & $\mathrm{f}_{\mathrm{m}}$ \\
Modulus of elasticity in parallel directions to the grain & $\mathrm{E}_{\mathrm{c} 0}$ \\
Modulus of elasticity in tension parallel to the grain & $\mathrm{E}_{\mathrm{t} 0}$ \\
Conventional modulus of elasticity on static bending test & $\mathrm{E}_{\mathrm{m}}$ \\
Hardness parallel to the grain & $\mathrm{f}_{\mathrm{H} 0}$ \\
Hardness normal to the grain & $\mathrm{f}_{\mathrm{H} 90}$ \\
Toughness & $\mathrm{W}$ \\
Compressive strength in normal direction to the grain & $\mathrm{f}_{\mathrm{c} 90}$ \\
\hline
\end{tabular}

\section{Results and Discussion}

Tables 2 and 3 shows the mean values $(\bar{x})$, coefficient of variation $(\mathrm{Cv})$, the lowest (Min) and the highest (Max) of the physical and mechanical properties of the Erisma uncinatum Warm wood, respectively.

Table 2. Physical properties results for the Erisma uncinatum Warm wood

\begin{tabular}{cccc}
\hline Stat. & $\boldsymbol{\rho}_{\mathbf{1 2}}\left(\mathbf{k g} / \mathbf{m}^{\mathbf{3}}\right)$ & RRT (\%) & RTT (\%) \\
\hline $\bar{x}$ & 680 & 5.83 & 10.55 \\
$C v$ & 0.05 & 0.12 & 0.09 \\
Mín & 620 & 4.72 & 8.85 \\
Máx & 740 & 7.02 & 12.19 \\
\hline
\end{tabular}


Table 3. Mechanical properties results for the Erisma uncinatum Warm wood

\begin{tabular}{|c|c|c|c|c|}
\hline Stat. & $\mathrm{f}_{\mathrm{c} 0}(\mathrm{MPa})$ & $\mathbf{f}_{\mathbf{t} 0}(\mathbf{M P a})$ & $\mathbf{f}_{\mathbf{t} 90}(\mathrm{MPa})$ & $\mathbf{f}_{\mathrm{v} 0}(\mathrm{MPa})$ \\
\hline $\bar{x}$ & 34 & 45 & 4.9 & 14 \\
\hline$C v$ & 0.15 & 0.30 & 0.15 & 0.16 \\
\hline Min & 27 & 31 & 4.2 & 11 \\
\hline Máx & 43 & 67 & 6.4 & 18 \\
\hline Stat. & $\mathbf{f}_{\mathrm{s} 0}(\mathbf{M P a})$ & $\mathbf{f}_{\mathrm{m}}(\mathbf{M P a})$ & $\mathrm{E}_{\mathrm{c} 0}(\mathrm{MPa})$ & $\mathrm{E}_{\mathrm{t} 0}(\mathrm{MPa})$ \\
\hline $\bar{x}$ & 0.8 & 63 & 12967 & 12764 \\
\hline$C v$ & 0.16 & 0.21 & 0.18 & 0.14 \\
\hline Min & 0.6 & 40 & 9732 & 10800 \\
\hline Máx & 1.0 & 82 & 16960 & 15887 \\
\hline Stat. & $\mathbf{E}_{\mathrm{m}}(\mathrm{MPa})$ & $\mathbf{f}_{\mathrm{H} 0}(\mathrm{MPa})$ & $\mathrm{f}_{\mathrm{H} 90}(\mathrm{MPa})$ & $\mathbf{W}(\mathbf{N} \cdot \mathbf{m})$ \\
\hline $\bar{x}$ & 12376 & 51 & 67 & 33.39 \\
\hline$C v$ & 0.07 & 0.09 & 0.12 & 0.19 \\
\hline Min & 10263 & 43 & 55 & 20.10 \\
\hline Máx & 13587 & 60 & 79 & 41.20 \\
\hline Stat. & \multicolumn{2}{|c|}{$\mathrm{f}_{\mathrm{c} 90}(\mathrm{MPa})$} & \multicolumn{2}{|c|}{$\mathrm{E}_{\mathrm{c90}}(\mathrm{MPa})$} \\
\hline $\bar{x}$ & \multicolumn{2}{|c|}{7.0} & \multicolumn{2}{|c|}{7095} \\
\hline$C v$ & \multicolumn{2}{|c|}{0.17} & \multicolumn{2}{|c|}{0.18} \\
\hline Min & \multicolumn{2}{|c|}{5.0} & \multicolumn{2}{|c|}{4812} \\
\hline Máx & \multicolumn{2}{|c|}{9.0} & \multicolumn{2}{|c|}{9148} \\
\hline
\end{tabular}

The Erisma uncinatum Warm timber is classified as belonging to strength class C20, because it shows a characteristic value of compressive strength in the direction parallel to the grain $\left(\mathrm{f}_{\mathrm{c} 0}\right)$ equal to $34 \mathrm{MPa}$.

The obtained $\mathrm{f}_{\mathrm{c} 0}$ value for the Erisma uncinatum Warm wood is very close to the value obtained for Paricá wood (24 MPa) [2], Toona ciliata (27MPa) [11] and Eucalyptus benthamii Maiden et Cambage (37.34MPa) [12]. According to the study of Institute for Technological Research (Instituto de Pesquisas Tecnológicas - IPT) [7], such timbers can be used in the manufacture of doors, shutters, slats, gaskets, ceilings, scaffolding, formwork, furniture, among other utilities. However, because it's significantly lower $\mathrm{f}_{\mathrm{c} 0}$ value compared to the Amescla-Aroeira wood (59.03 $\mathrm{MPa}$ ) [13], the Erisma uncinatum Warm wood is not recommended for use in medium to large structures.

The mean value obtained from the apparent density of $0.680 \mathrm{~g} / \mathrm{cm}^{3}$ classifies Erisma uncinatum Warm wood as a heavy wood [14], with the same classification as Minquartia guianensis, Lecythis poiteaui, Mezilaurus itauba, Manilkara huberi and Brosimum rubescens [10]. However, Erisma uncinatum Warm wood is lighter, since the density of the other ranging from $0.835-0.904 \mathrm{~g} / \mathrm{cm}^{3}$. It has higher density as compared to the wood densities of Liquidambar sp. [15], Pinus and Teca [2], Cedrela fissilis, Hibrido clonal and Hovenia dulcis [16], ranging between 0.478 and $0.577 \mathrm{~g} / \mathrm{cm}^{3}$.
The softwoods, such as Toona ciliata [11], Paricá [6] and Gallesia integrifólia [16] presents density value range between $0.318 \mathrm{~g} / \mathrm{cm}^{3}$ and $0.370 \mathrm{~g} / \mathrm{cm}^{3}$.

The Brazilian standard ABNT NBR 7190 [9] determines maximum values for the coefficient of variation $(C v)$ for the characterization could be described as adequate, being $18 \%$ to the strength to normal efforts and $28 \%$ for tangential efforts. All properties met the values of the coefficients of variation required by the standard, but the tensile strength parallel to the fibers $\left(f_{t 0}\right)$, which exceeded the limit, showing a $C v$ equal to 0.30 .

Tables 4 and 5 shows the best fits (by property) obtained using regression models for apparent density in the estimation of the values of strength and stiffness, respectively.

Table 4. Regression models for the strength values estimation of the Erisma uncinatum Warm by the apparent density

\begin{tabular}{cccccc}
\hline & Model & P-value & $\mathbf{a}$ & $\mathbf{b}$ & $\mathbf{R}^{\mathbf{2}} \mathbf{( \% )}$ \\
\hline $\mathbf{f}_{\mathbf{c 0}}$ & Exp & 0.7016 & 50.67 & -0.57 & 1.53 \\
$\mathbf{f}_{\mathbf{t 0}}$ & Lin & 0.0985 & -98.48 & 212.79 & 24.90 \\
$\mathbf{f}_{\mathbf{9 0} 0}$ & Geo & 0.4459 & 3.64 & -0.73 & 5.92 \\
$\mathbf{f}_{\mathbf{v 0}}$ & $\log$ & 0.5651 & 17.73 & 8.47 & 3.42 \\
$\mathbf{f}_{\mathbf{s 0}}$ & Geo & 0.5281 & 1.059 & 0.69 & 4.10 \\
$\mathbf{f}_{\mathbf{m}}$ & Geo & 0.8598 & 69.01 & 0.27 & 0.33 \\
$\mathbf{f}_{\mathbf{H 0}}$ & $\log$ & 0.6411 & 45.69 & -14.17 & 2.26 \\
$\mathbf{f}_{\mathbf{H 9 0}}$ & $\operatorname{Exp}$ & 0.5538 & 108.70 & -0.73 & 3.62 \\
$\mathbf{W}$ & $\log$ & 0.4417 & 20.76 & -32.25 & 6.03 \\
$\mathbf{f}_{\mathbf{c 9 0}}$ & $\operatorname{Exp}$ & 0.2730 & 2.0860 & 1.73 & 11.86 \\
\hline
\end{tabular}

Table 5. Regression models for the stiffness values estimatimation of the Erisma uncinatum Warm by the apparent density

\begin{tabular}{cccccc}
\hline & Model & P-value & $\mathbf{a}$ & $\mathbf{b}$ & $\mathbf{R}^{\mathbf{2}} \mathbf{( \% )}$ \\
\hline $\mathbf{E}_{\mathbf{c 0}}$ & Exp & 0.51 & 28219.7 & -1.17 & 4.38 \\
$\mathbf{E}_{\mathbf{t 0}}$ & Log & 0.20 & 6900.37 & -14972.6 & 15.31 \\
$\mathbf{E}_{\mathbf{m}}$ & Exp & 0.06 & 27346 & -1.17 & 29.18 \\
$\mathbf{E}_{\mathbf{c 9 0}}$ & Lin & 0.14 & -4997.41 & 17870.9 & 19.73 \\
\hline
\end{tabular}

P-values above 5\% from ANOVA regression models revealed the non-representativeness of the tested settings, showing that the apparent density not to be a good estimator of the strength and stiffness values for the Erisma Warm uncinatum timber.

The values of the coefficient of determination $\left(\mathrm{R}^{2}\right)$ near to $80 \%$ for the toughness estimated by apparent density obtained from Almeida et al. [2] were significantly higher compared to the values of the coefficient of determination in the estimation of the toughness $(6.03 \%)$ obtained for Erisma uncinatum Warm wood. This result is justified by the use of various species of wood and different densities explored in Almeida et al. [2] research, which ended up favoring the quality of the obtained settings. 


\section{Conclusions}

The results of this study allow us to conclude:

- From the obtained coefficient of variation values, the characterization of Erisma uncinatum Warm species can be considered in accordance with the required by the Brazilian standard [9].

- Erisma uncinatum Warm wood is classified into C20 strength class, because it presents a characteristic value of compressive strength $\left(\mathrm{f}_{\mathrm{c} 0, \mathrm{k}}\right)$ equal to $34 \mathrm{MPa}$. Thus, it can be used in doors, shutters, strips, gaskets, liners, scaffolds, molds, furniture, and other utilities.

- The estimation of strength and stiffness values of the Erisma uncinatum Warm wood depending on the apparent density provided no significant adjustments by the regression models, showing unsuitable use of such estimation for this kind of wood.

\section{ACKNOWLEDGMENTS}

For all the provided support, the authors thanks the Coordenação de Aperfeiçoamento de Nível Superior (CAPES) and the Conselho Nacional de Desenvolvimento Científico e Tecnológico (CNPq).

\section{REFERENCES}

[1] Almeida, D. H.; Chahud, E.; Almeida, T. H.; Christoforo, A. L.; Branco, L. A. M. N.; Lahr, F. A. R. Determination of Density, Shear and Compression Parallel to the Grain Strengths of Pariri (Pouteria sp.), Brazilian Native Wood Specie, International Journal of Materials Engineering 2015, 5(5): 109-112.

[2] Almeida, D. H.; Scaliante, R. M.; Christoforo, A. L.; Varanda, L. D.; Lahr, F. A. R.; Dias, A. A.; Junior, C. C. Tenacidade da madeira como função da densidade aparente, Revista Árvore, Viçosa-MG, v.38, n.1, p.203-207, 2014.

[3] Souza, M. H.; Incentivo ao uso de novas madeiras para a fabricação de móveis, IBAMA, Brasília, 70p, 1997.

[4] Christoforo, A. L.; Blecha, K. A.; Carvalho, A. L. C.; Rezende, L. F. S.; Lahr, F. A. R. Characterization of Tropical Woods Species for Use in Civil Constructions, Journal of Civil Engineering Research 2013, 3(3): 98-103.

[5] Lahr, F. A. R.; Propriedades físicas de resistência e de elasticidade de espécies de madeira para emprego em estruturas, Encontro Brasileiro de Madeiras e em Estruturas de Madeiras, v. 3, São Carlos, SP, Brasil, 1989.
[6] Almeida, D. H.; Scaliante, R. M.; Macedo, L. B.; Macêdo, A. N.; Dias, A. A.; Christoforo, A. L.; Junior, C. A. Caracterização completa da madeira da espécie amazônica Paricá (Schizolobium amazonicum HERB) em peças de dimensões estruturais, Revista Árvore, Viçosa-MG, v.37, n.6, p.1175-1181, 2013.

[7] Instituto De Pesquisas Tecnológicas Do Estado De São Paulo. Madeira: uso sustentável na construção civil. São Paulo, disponível em: http://www.ipt.br/informacoes_madeiras/9.ht m, acesso em: 01 de Junho de 2016.

[8] Zangiácomo, A. L.; Lahr, F. A. R. Emprego de espécies tropicais alternativas na produção de elementos estruturais de madeira laminada colada. Cadernos de Engenharia de Estruturas, São Carlos, v. 9, n. 40, p. 103-131, 2007.

[9] Associação Brasileira De Normas Técnicas - ABNT. NBR 7190. Projeto de estruturas de madeira. Rio de Janeiro, 107 p., 1997.

[10] Silveira, L. H. C.; Rezende, A. V.; Vale, A. T. Teor de umidade e densidade básica da madeira de nove espécies comerciais amazônicas, Acta Amazônica, Vol. 43(2) 2013: 179-184.

[11] Braz, R. L.; Oliveira, J. T. S.; Rodrigues, B. P.; Arantes, M. D. C. Propriedades físicas e mecânicas da madeira de Toona ciliata em diferentes idades, FLORESTA, Curitiba, PR, v.43, n.4, p.663-670, out/dez, 2013.

[12] Müller, B. V.; Rocha, M. P.; Cunha, A. B.; Klitzke, R. J.; Nicoletti, M. F. Avaliação das Principais Propriedades Físicas e Mecânicas da Madeira de Eucalyptus benthamii Maiden et Cambage, Floresta e Ambiente 2014 out./dez.; 21(4): 535-542.

[13] Logsdon, N. B.; Finger, Z.; Estevão, J. G. Descrição Dendrológica e caracterização físico-mecânica da madeira de Amescla-aroeira, Protium heptaphyllum (Aubl) March. (Burseraceae), Revista Madeira Arquitetura e Engenharia, ano 6, Set-Dez. 2005.

[14] Melo, J. E.; Coradin, V. T. R.; Mendes, J. C. Classes de densidade de madeira para a Amazônia brasileira. In: Anais do Congresso Florestal brasileiro 6:695-699. São Paulo, SP, Brasil, 1990.

[15] Freitas, T. P.; Feuchard, L. D.; Oliveira, J. T. S.; Paes, J. B.; Arantes, M. D. C. Caracterizações anatômicas e físico-mecânica da madeira de Liquidambar sp., FLORESTA, Curitiba, PR, v.45, n.4, p.723-734, out/dez, 2015.

[16] Motta, J. P.; Oliveira, J. T. S.; Braz, R. L.; Duarte, A. P. C., Alves, R. C. Caracterização da madeira de quatro espécies florestais, Ciência Rural, Santa Maria, V.44, n.12, p.2186-2192, dez, 2014.

[17] Montgomery, D. C. Design and analysis if experiments. Arizona: John Wiley \& Sons, 2012, 730p. 